\title{
Improving the Reading Ability of Students Using the Cooperative Integrated Reading and Composition (CIRC) Method in Class IV SDN 3 Cilangkap
}

\author{
Heni Ratnasari, Riga Zahara Nurani, Winarti Dwi Febriani \\ Universitas Perjuangan Tasikmalaya \\ heniratnasari192@gmail.com
}

\section{Article History}

accepted 05/11/2020

approved 10/11/2020

published 01/02/2021

\begin{abstract}
This study aims to improve students' reading comprehension skills by using the Cooperative Integrated Reading and Composition (CIRC) method. This research method was conducted in 3 cycles using a classroom action research design belonging to Kemmis and Mc Taggart. In implementing this research, the steps of the Cooperative Integrated Reading and Composition (CIRC) method are used, which are divided into three stages, namely the opening activity, the core activity, and the closing activity. The results of the research in the first cycle obtained an average value of 78.6 with the percentage of students who had completed $70 \%$ and those who had not completed were $30 \%$. Furthermore, in the second cycle an average score of 85.5 was obtained with the percentage of students who had completed $90 \%$ and those who had not completed were $10 \%$. Meanwhile, in cycle III, an average score of 89.8 was obtained with the percentage of students who completed $100 \%$. The results obtained, namely the Cooperative Integrated Reading And Composition (CIRC) method can improve reading comprehension skills of fourth grade students of SDN 3 Cilangkap, Tasikmalaya Regency.
\end{abstract}

Keywords: Cooperative Integrated Reading And Composition (CIRC), reading skills

\begin{abstract}
Abstrak
Penelitian ini bertujuan untuk meningkatkan kemampuan membaca pemahaman siswa dengan menggunakan metode Cooperative Integrated ReadingAnd Composition (CIRC). Metode penelitian ini dilakukan dalam 3 siklus dengan menggunakan desain penelitian tindakan kelas milik Kemmis dan Mc Taggart. Dalam pelaksanaannya penelitian ini menggunakan langkahlangkah metode Cooperative Integrated ReadingAnd Composition (CIRC) yang dibagi menjadi tiga tahapan yaitu kegiatan pembuka, kegiatan inti, dan kegiatan penutup. Hasil penelitian pada siklus I diperoleh nilai rata-rata 78,6 dengan persentase siswa yang tuntas sebesar $70 \%$ dan siswa yang belum tuntas sebesar $30 \%$. Selanjutnya pada siklus II diperoleh nilai rata-rata 85,5 dengan persentase siswa yang tuntas sebesar $90 \%$ dan siswa yang belum tuntas sebesar $10 \%$. Sedangkan padas iklus III diperoleh nilai rata-rata 89,8 dengan persentase siswa yang tuntas sebesar $100 \%$. Hasil yang diperoleh yaitu metode Cooperative Integrated Reading And Composition (CIRC) dapat meningkatkan kemampuan membaca pemahaman siswa kelas IV SDN 3 Cilangkap Kabupaten Tasikmalaya.
\end{abstract}

Kata kunci: Cooperative Integrated ReadingAnd Composition (CIRC), kemampuan membaca

Social, Humanities, and Education Studies (SHEs): Conference Series https://jurnal.uns.ac.id/shes

p-ISSN 2620-9284

e-ISSN 2620-9292 


\section{PENDAHULUAN}

Membaca merupakan hal yang wajib bagi semua orang terutama pada siswa sekolah dasar. Karena dengan membaca siswa akan lebih memahami suatu teks bacaan, dan dengan banyak membaca pula siswa dapat mengembangkan keterampilan berbahasa lainnya. Hal tersebut sejalan dengan pendapat Hodgson (dalam Delviani, dkk:2016) yang menyatakan bahwa "membaca suatu proses perolehan pesan." Keterampilan membaca dapat diajarkan kepada siswa pada jenjang pendidikan dasar. Oleh karena itu, keterampilan membaca di Sekolah Dasar harus ditangani dengan tepat.

Seperti yang tercantum dalam Permendikbud No 67 Tahun 2013 Tentang Kerangka Dasar dan Struktur Kurikulum yang menyatakan: "Proses pendidikan adalah suatu proses yang memberi kesempatan kepada peserta didik untuk mengembangkan potensi dirinya menjadi kemampuan berpikir rasional dan kecemerlangan akademik dengan memberikan makna terhadap apa yang dilihat, didengar, dibaca, dipelajari, dari warisan budaya berdasarkan makna yang ditentukan oleh lensa budayanya dan sesuai dengan tingkat kematangan psikologis serta kematangan peserta didik".

Pada siswa kelas IV sudah harus bisa memahami suatu bacaan. Karena membaca merupakan salah satu kemampuan dasar yang wajib dimiliki oleh setiap individu. Apalagi didalam pembelajaran Bahasa Indonesia tidak hanya sekedar membaca, tetapi harus memahami isi teks bacaan dan harus mencapai nilai KKM. Karena tujuan akhir dari membaca adalah memahami isi bacaan. Akan tetapi pada kenyataan di lapangan terdapat 8 siswa kelas IV di SDN 3 Cilangkap yang belum bisa memahami isi bacaan. Dari 8 siswa tersebut, mereka lancar membaca akan tetapi mereka tidak paham apa isi teks bacaan tersebut. Maka dari itu berdasarkan permasalahan tersebut, pada penelitian ini akan melakukan penelitian mengenai kemampuan membaca pemahaman siswa di kelas IV SDN 3 Cilangkap Kabupaten Tasikmalaya.

Tujuan dari penelitian ini adalah untuk mengetahui pembelajaran kemampuan membaca pemahamana siswa kelas IV SDN 3 Cilangkap. Pembelajaran kemampuan membaca pemahaman siswa di kelas IV SDN 3 Cilangkap dengan menggunakan metode Cooperative Integrated Reading And Composition (CIRC). Karena metode $\mathrm{CIRC}$ adalah kegiatan pembelajaran membaca terkait pengajaran langsung memahami bacaan dan seni berbahasa menulis terpadu yang dikemukakan oleh Abidin (dalam Niliawati, dkk:2018).

\section{METODE}

Metode penelitian ini dilakukan dengan menggunakan metode PTK (Penelitian Tindakan Kelas) dalam 3 siklus dengan menggunakan desain penelitian tindakan kelas milik Kemmis dan Mc Taggart. Dengan perencanaan penelitian yang terbagi kedalam empat tahapan yaitu : 1. perencanaan 2. pelaksanaan 3. observasi 4. refleksi.

Menurut Kurniasih (Oktaviani, dkk:2018) menyebutkan CIRC, yaitu sebuah program yang komprehensif untuk mengajari pelajaran membaca, menulis, dan seni berbahasa di sekolah dasar. Hal ini berkaitan dengan tujuan utama dari CIRC yaitu menggunakan kelompok-kelompok kooperatif untuk membantu siswa dalam mempelajari kemampuan dalam memahami bacaan yang dapat diterapkan secara luas.

Adapun menurut Abidin (Khasanah, dkk:2016) metode CIRC adalah kegiatan pembelajaran membaca terkait pengajaran langsung memahami bacaan dan seni berbahasa menulis terpadu.

Langkah-langkah Pembelajaran Metode Cooperative Integrated Reading And Composition (CIRC) 
Berikut langkah-langkah metode CIRC menurut Berlin Sani (Oktafiani, dkk:2018) sebagai berikut:

1. Guru menjelaskan tujuan pembelajaran dan membentuk kelompok yang anggotanya 4 - 5 siswa.

2. Guru memberikan materi berupa wacana/kliping sesuai dengan topik pembelajaran yang akan diajarkan pada saat itu.

3. Siswa bekerja sama saling membacakan dan menemukan ide pokok kemudian memberi tanggapan hasil kerja kelompok mereka terhadap wacana/kliping dan ditulis pada lembar kertas.

4. Kemudian siswa mempresentasikan atau membacakan hasil kerja kelompok. Setelah itu guru kepada siswa memberikan latihan menjawab pertanyaan.

5. Selesai mengerjakan latihan yang diberikan oleh guru kepada siswa, selanjutnya guru bersama-sama dengan siswa membuat kesimpulan bersama setelah itu guru menutup pelajaran seperti biasanya.

a. Perencanaan

\section{HASIL DAN PEMBAHASAN}

Pada siklus I, terlebih dahulu dipersiapkan perangkat pembelajaran yang terdiri dari perencanaan sebagai berikut:

1. Membuat Rencana Pelaksanaan Pembelajaran (RPP)

2. Menyiapkan teks bacaan cerita yang berjudul Dampak Lingkungan Kotor dan Peduli Sampah dan soal pertanyaan

3. Lembar Observasi Guru Proses Pembelajaran Kemampuan Membaca Pemahaman Siswa.

b. Pelaksanaan Tindakan dan Hasil Observasi

Penelitian ini penelitian tindakan kelas dari siklus Kemmis dan Mc Taggart. Dan dikaitkan dengan rumusan serta tujuan masalah pada penelitian ini. Pada pelaksanaan siklus I dilaksanakan sesuai perencanaan yang telah dibuat yaitu melaksanakan kegiatan pendahuluan pembelajaran dimulai dengan mengucapkan salam, menanyakan kabar siswa, dan melakukan kegiatan do'a bersama. Kemudian inti pembelajaran dengan menggunakan metode CIRC dimulai dengan penulis melakukan komunikasi dengan siswa seputar materi pemahaman isi teks cerita Dampak Lingkungan Kotor dan Peduli Sampah. Kegiatan penutup penulis memberikan kesempatan kepada siswa bertanya tentang materi yang telah dipelajari berdasarkan pemahaman yang sudah didapatkannya selama kegiatan pembelajaran.

Hasil dari kemampuan membaca pemahaman siswa pada siklus I masih banyak siswa yang belum tuntas dalam kemampuan memahami bacaan yaitu $70 \%$ tuntas dan $30 \%$ yang belum tuntas dengan nilai rata-rata 78,6 . Maka dari itu, akan dilakukan perbaikan untuk dilaksanakan pada siklus selanjutnya yaitu pada siklus II. Berikut tabel dan diagram hasil kegiatan pembelajaran siklus I:

Tabel 1. Hasil Siklus I

\begin{tabular}{ccc}
\hline Tuntas & Belum Tuntas & Nilai Rata-rata \\
\hline $70 \%$ & $30 \%$ & 78,6 \\
\hline
\end{tabular}




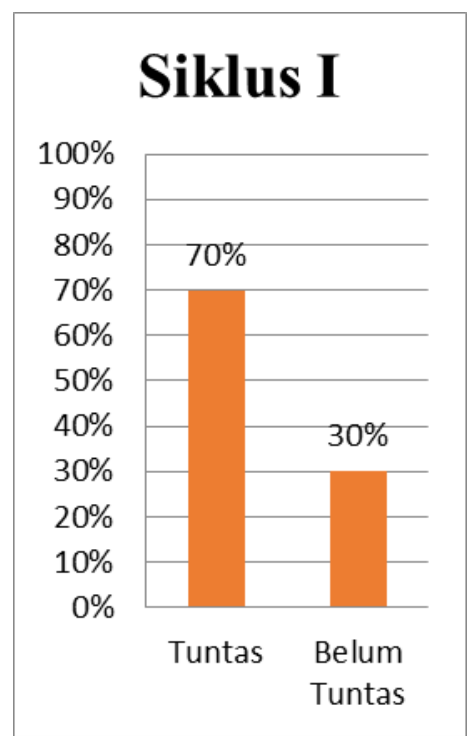

c. Refleksi

\section{Gambar 1. Diagram Persentase Ketuntasan Belajar Siklus I}

Berdasarkan observasi siklus I dengan menggunakan metode CIRC, dilihat dari hasil belajar kemampuan membaca pemahaman siswa siklus I nilai rata-rata yaitu 78,6. Dengan ketuntasan $70 \%$ dan yang belum tuntas 30\%. Berdasarkan hal tersebut maka dapat disimpulkan bahwa kegiatan pada siklus I ini masih banyak kekurangan dan harus dibuat perencanaan siklus II.

a. Perencanaan

Pada siklus II, terlebih dahulu dipersiapkan perangkat pembelajaran perbaikan dari siklus II yang terdiri dari perencanaan sebagai berikut:

1. Membuat Rencana Pelaksanaan Pembelajaran (RPP).

2. Menyiapkan teks bacaan cerita yang berjudul Berlibur ke Taman Safari.

3. Lembar Observasi Guru Proses Pembelajaran Kemampuan Membaca Pemahaman Siswa.

b. Pelaksanaan dan Hasil Observasi

Pada pelaksanaan siklus II dimulai dengan kegiatan pendahuluan yaitu mengucapkan salam, menanyakan kabar siswa dan berdo,a. Kemudian kegiatan inti pembelajaran kemampuan membaca pemahaman siswa dengan materi teks bacaan Berlibur ke Taman Safari dan mengaitkan pembelajaran dengan materi sebelumnya. Selanjutnya kegiatan penutup yaitu bertanya jawab dengan siswa dan menyimpulkan hasil pembelajaran pada siklus II.

Adapun hasil perbaikan kemampuan membaca pemahaman siswa pada siklus II dengan ketuntasan $90 \%$ dan $10 \%$ belum tuntas dengan nilai rata-rata 85,5 . Dari hasil siklus II, dapat dilihat bahwa pembelajaran yang dilakukan, kemampuan membaca pemahaman siswa siklus II masih harus ada perbaikan selanjutnya yaitu siklus III. Berikut tabel dan diagram hasil kegiatan pembelajaran siklus II:

\section{Tabel 2. Hasil Siklus II}

\begin{tabular}{ccc}
\hline Tuntas & Belum Tuntas & Nilai Rata-rata \\
\hline $90 \%$ & $10 \%$ & 85,5 \\
\hline
\end{tabular}




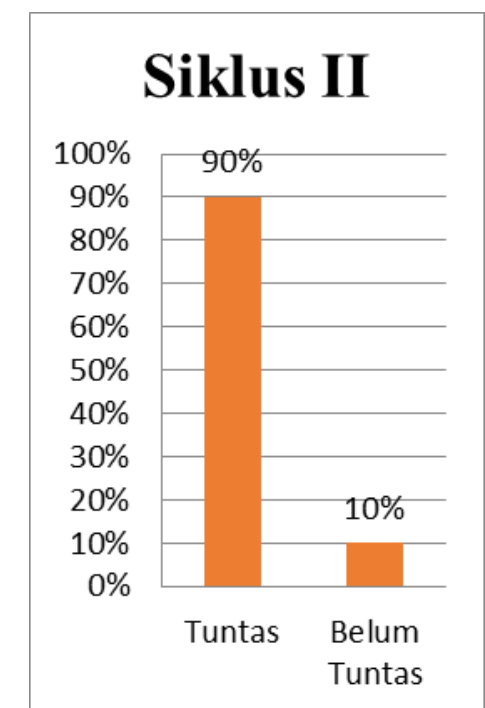

c. Refleksi

\section{Gambar 2. Diagram Persentase Ketuntasan Belajar Siklus II}

Hasil siklus II kegiatan pembelajaran kemampuan membaca pemahaman siswa dengan ketuntasan $90 \%$ dan yang belum tuntas $10 \%$ dengan nilai rata-rata 85,5 . Pada siklus II ini harus ada perbaikan selanjutnya yaitu siklus III dengan harapan dapat meningkatkan kemampuan membaca pemahaman siswa di kelas IV SDN 3 Cilangkap.

a. Perencanaan

Pada siklus III, perencanaan pelaksanaan yaitu membuat perencanaan pelaksanaan pembelajaran sesuai dengan perbaikan dari hasil siklus II sebagai berikut:

1. Membuat Rencana Pelaksanaan Pembelajaran (RPP).

2. Menyiapkan teks bacaan cerita yang berjudul Manfaat Helm.

3. Lembar Observasi Guru Proses Pembelajaran Kemampuan Membaca Pemahaman Siswa.

\section{b. Pelaksanaan}

Kegiatan pelaksanaan pembelajaran siklus III dimulai dari kegiatan pendahuluan yaitu dengan mengucapkan salam, menanyakn kabar siswa dan berdo'a. Kemudian pada kegiatan inti sama dengan pada pembelajaran siklus II dengan materi yang berbeda. Kemudian kegiatan pembelajaran tersebut dikaitkan dengan pembelajaran materi sebelumnya. Selanjutnya kegiatan penutup dengan melakukan tanya jawab dengan siswa dan menyimpulkan hasil kegiatan pembelajaran pada siklus III.

Dari kegiatan pembelajaran kemampuan membaca pemahaman siswa pada siklus III dapat dilihat bahwa hasil kemampuan membaca pemahaman siswa dari setiap siklus ada peningkatan dari siklus I dan siklus II. Hasil yang didapatkan dari pelaksanaan siklus III yaitu dengan ketuntasan $100 \%$ dengan nilai rata-rata 89,8 . Dilihat dari ketuntasan setiap siklus bahwa pembelajaran kemampuan membaca pemahaman dengan menggunakan metode CIRC dapat membantu meningkatkan kemampuan membaca pemahaman siswa kelas IV SDN 3 Cilangkap. Berikut tabel dan diagram hasil kegiatan pembelajaran siklus III:

\section{Tabel 3. Hasil Siklus II}

\begin{tabular}{ccc}
\hline Tuntas & Belum Tuntas & Nilai Rata-rata \\
\hline $100 \%$ & $0 \%$ & 89,8 \\
\hline
\end{tabular}




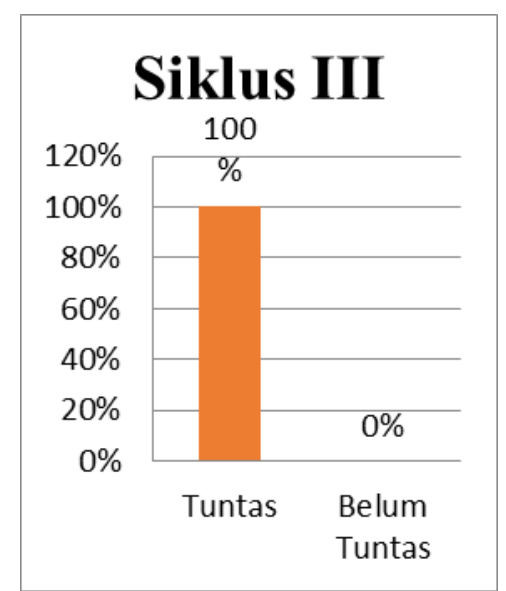

Gambar 3. Diagram Persentase Ketuntasan Belajar Siklus III

Hasil-hasil tersebut didapatkan dari setiap siklus yang telah dilaksanakan oleh peneliti dengan proses perbaikan. Nilai yang didapatkan oleh seluruh siswa kelas IV SDN 3 Cilangkap akan dibandingkan setiap siklusnya sebagai berikut:

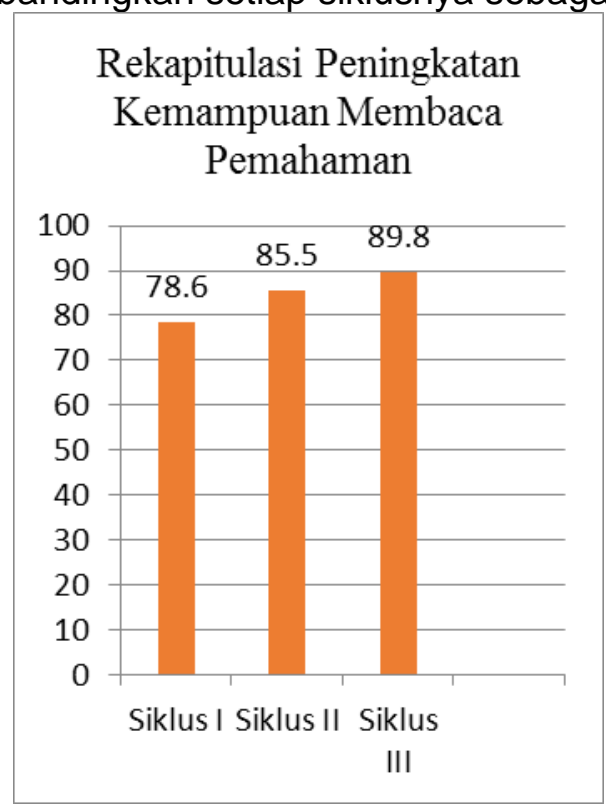

Gambar 4. Diagram Rata-rata Nilai Ketuntasan Belajar Persiklus

Dari diagram diatas dapat dilihat bahwa nilai rata-rata yang didapatkan siswa kelas IV SDN 3 Cilangkap pada kemampuan membaca pemahaman siswa mengalami peningkatan yaitu dengan nilai rata-rata pada siklus I 78,6, Siklus II 85,5 dan siklus III dengan nilai rata-rata 89,8 . Peningkatan siswa tersebut setelah melakukan penerapan dengan menggunakan metode Cooperative Integrated Reading And Composition (CIRC).

Perencanaan dan pelaksanaan kegiatan pembelajaran kemampuan membaca pemahaman siswa dengan menggunakan metode Cooperative Integrated Reading And Composition (CIRC) untuk meningkatkan kemampuan membaca pemahaman siswa. Dengan tahap perencanaan ini peneliti menyusun beberapa tahap untuk dilaksanakan agar pelaksanaan tindakan siklus I, siklus II, dan siklus III berjalan sesuai dengan tujuan diantaranya menyusun RPP dengan menggunakan langkah-langkah metode Cooperative Integrated Reading And Composition (CIRC), mempersiapkan materi teks bacaan cerita nonfiksi yang setiap siklusnya berbeda-beda. Selanjutnya penulis menyiapkan lembar observasi guru proses kegiatan pembelajaran kemampuan 
membaca pemahaman siswa untuk mengetahui sejauh mana penulis menggunakan metode Cooperative Integrated Reading And Composition (CIRC) di kelas IV SDN 3 Cilangkap dengan baik.

Peningkatan kemampuan membaca pemahaman siswa pada siklus I dengan nilai rata-ratanya adalah 78,6 dari $70 \%$ yang tuntas dan $30 \%$ yang belum tuntas. Pada siklus I ini sebagian siswa belum bisa memenuhi aturan yang telah ditentukan sehingga banyak siswa yang belum tuntas atau berhasil pada pembelajaran siklus ke I. Pada siklus II nilai rata-ratanya adalah 85,5 dari $90 \%$ yang tuntas dan $10 \%$ yang belum tuntas. Pada siklus ke II menunjukkan bahwa ada cukup peningkatan membaca pemahaman siswa dari siklus I. Pada siklus ke III ketuntasan membaca pemahaman siswa $100 \%$ dengan nilai rata-ratanya adalah 89,8 hal ini menunjukkan bahwa penggunaan metode Cooperative Integrated Reading And Composition (CIRC) dapat meningkatkan kemampuan membaca pemahaman siswa di kelas IV SDN 3 Cilangkap Kabupaten Tasikmalaya.

\section{SIMPULAN}

Perencanaan penelitian Peningkatan kemampuan membaca pemahaman siswa dengan menggunakan metode Cooperative Integrated Reading And Composition (CIRC) ini dibagi ke dalam 3 siklus dengan masing-masing siklus terdiri dari empat tahapan yaitu, perencanaan, pelaksaan, observasi dan refleksi dengan menggunakan siklus milik Kemmis dan Mc Taggart. Penelitian ini dilaksanakan pada pelajaran Bahasa Indonesia materi kemampuan membaca pemahaman dengan menggunakan metode Cooperative Integrated Reading And Composition (CIRC) dengan 3 siklus.di kelas IV SDN 3 Cilangkap Kabupaten Tasikmalaya.

Hasil dari penelitian ini menunjukkan adanya peningkatan hal ini dibuktikan pada siklus I dengan nilai rata-rata adalah 78,6 dengan tuntas $70 \%$ dan $30 \%$ yang belum tuntas. Siklus II dengan nilai rata-rata 85,5 dengan tuntas $90 \%$ dan $10 \%$ yang belum tuntas. Pada siklus III ketuntasan kemampuan membaca pemahaman siswa $100 \%$ dengan nilai rata-rata 89,8 . Peningkatan ini terjadi karena penulis melakukan kegiatan pembelajaran dengan perencanaan, tindakan dan hasil. Respon dan motivasi kepada siswa untuk belajar membaca terus meningkat dan melampaui nilai Kriteria Ketuntasan Minimal (KKM) dalam membaca pemahaman siswa yaitu 75.

\section{DAFTAR PUSTAKA}

Delviani, dkk. (2016). Penerapan Model Kooperatif Tipe CIRC (Cooperative Integrated Reading And Composition) Berbantuan Media Puzzle Kalimat Untuk Meningkatkan Kemampuan Membaca Anak Dalam Menentukan Pikiran Pokok. Jurnal Pena IImiah, Vol 1 No 1 Tahun 2016.

Khasanah, dkk. (2016). Peningakatan Membaca Pemahaman Dengan Strategi Question Answer Relationship (QAR) Pada Siswa Kelas V Sekolah Dasar. Jurnal Pedagogik Pendidikan Dasar, Jilid 4 Nomor 2, Juli 2016, Hal. 161-175.

Niliawati, dkk. (2018). Penerapan Metode CIRC (Cooperative Integrated Reading And Composition) Untuk Meningkatkan Kemampuan Membaca Pemahaman Siswa Kelas IV. Jurnal Pendidikan Guru Sekolah Dasar, Vol. III No. I, April 2018, hlm. 23-34.

Oktaviani, dkk. (2018). Efektivitas Pembelajaran Cooperative Integrated Reading And Composition (CIRC) Untuk Meningkatkan Kemampuan Membaca Pemahaman Anak Disleksia. UNES Journal of Education Scienties (UJES). Vol. 2, Issue 1, May 2018:17-22.

Permendikbud. (2013). Undang-undang RI No. 67 Tahun 2013. Tentang Kerangka Dasar dan Struktur Kurikulum 